\title{
The author's pedagogical model of health's formation among russian judokas of preschool age
}

\author{
Darya Mikhaylova ${ }^{1 *}$ \\ ${ }^{1}$ Law and Civil Security's Department of Management and Social Technologies' Institute, Theory and \\ Methods of Physical Culture's Department of Martial Arts and Non-Olympic Sports' Faculty, The \\ Federal State Budget Educational Institution of the Higher Education "National State University of \\ Physical Culture, Sport and Health named after P. F. Lesgaft, Saint-Petersburg”, Saint-Petersburg, \\ Russia
}

\begin{abstract}
This article examines the scientific problem of health's formation among Russian (non-oriented) judokas of preschool age through their early immersion in judo practice. The solution to this scientific problem is extremely important in the context of the necessity to form a special creative kids' ability to "adapt as quickly as possible to a partner / changing situation, anticipating the result, with minimal costs and maximum achievement of the chosen goal", which determines the effectiveness of mastering and practicing judo. Complex analysis of the judo's phenomenon in the context of main types and components of health allows us to consider it in four dimensions: social (level of communication), spiritual (level of consciousness), soulful (level of subconscious and unconscious) and physical (level of corporeality). The application of the method of theoretical modeling made it possible to propose the author's pedagogical model of judokas' health formation through the dual practice of judo: judo as a life principle (the judo's practice number one) and judo as the eastern system of formation of a person's physical culture (the judo's practice number two). The author's pedagogical model of health's formation among Russian judokas of preschool age is based on the implementation of the judo's practice number two. The effectiveness of this author's pedagogical model has been confirmed experimentally.
\end{abstract}

\section{Introduction}

\section{Definition of concepts}

Human health is the state of his complete physical, mental and social well-being, and not only the absence of diseases and physical defects; in health-care statistics human health at the individual level is understood as the absence of identified disorders and diseases, and at the population level - the process of reducing the level of mortality, morbidity and disability (according to the charter of the World Health Organization) [1].

\footnotetext{
* Corresponding author: $\underline{\mathrm{d}-\mathrm{samuray} @ \text { yandex.ru }}$
} 
Social health of a person [2] is the awareness of oneself as a full-fledged personality in the layer of society in which a person is (in the author's processing).

Mental health of a person is the normal course of his mental processes [2]; in our view, it includes two components: spiritual (conscious) human health and soulful (subconscious and unconscious) human health.

Spiritual health of a person is a person's thinking system and his attitude to the world around him [2-3].

Soulful health of a person - sensory, emotional, "subcortical" mental health of a person, his ability to create in general and insight as its main component in particular (author's definition).

Physical health of a person is the optimal course of all physiological processes and the absence of health complaints against the background of high immunity [2].

Natural human health is a complex of inclinations received by him at the genetic level and determining the success of his natural development (author's definition).

Adaptive human health is a state of well-being, in which a person can realize his own potential, cope with ordinary life stresses, work productively and fruitfully, and also contribute to the life of his community (the author's approach to identifying a more accurate name for an already known definition; according to World Health Organization - mental health of a person [4]).

Buffer human health - the ability to effectively solve the tasks set by the activity in extreme conditions without reducing its productivity and with a minimum of costs for the body; "protective" health, "health plus", "health with a reserve", "reserved health" (author's definition). One of the powerful technologies used by digital education is distance education technology [3].

At the same time, it is obvious, that there is also an integrative version of spiritual, soulful and physical health - psycho-corporal health.

Judo - "soft way" ("soft / flexible way / method"). Judo as an Olympic sport is a kind of wrestling, that "is tactically flexible and creative, maximally actualizes intellectual abilities, stimulates non-standard solutions, predetermines non-repeating puzzles of movements, creating conditions for selective manifestation of abilities, that are most adequate to specific situations".

"Four-dimensional judo" is a terminological version of a complex interpretation of the concept of judo, which characterizes the synthesis of socio-psychological, culturalgnoseological, intuitive (properly creative) and bodily potentials of its beneficial effect on practicing adepts.

\section{Literature review}

Determination of the relevance and the scientific novelty of the research

Pedagogical models as technological guidelines for sports' training in judo are now, as before, of considerable interest [5].

Thus, the results of modern researches on the theory, methodology and practice of judo in leading Russian rating scientific journals allow us to conclude that pedagogical models of health formation among young Russian judokas remain an unexplored topic, which determines the scientific novelty of our research. In particularly, the most demanded for research's analysis topics in the historical retrospective include: technical and tactical training of judokas [6], strength training of judokas [7-9], physiological aspects of sports' training in judo [10-11], endurance of judokas [12-13], special preparedness of judokas [14], peculiarities of the training process in judo [15-17], psychological training of judokas [18-19], increasing the effectiveness of competitive activity in judo [20-22], information support of educational and training process in judo [23], anthropometric characteristics of 
judokas [24-25], biomechanical aspects in the theory and practice of judo [26-31], increasing the effectiveness of pre-competitive training in judo [32-33], training of psychomotor and rapidity's abilities of judokas [34-35], strategies and versions of tactics in judo [36-37], national sports in training of judokas [38], genetic aspects of successfulness in judo [39].

At the same time, in fairness, it should be noted that today a number of Russian researches already concerns the development of pedagogical technologies in judo for preschool kids [40-41] and for kids of primary school age [42-45], but, nevertheless, these researches are not related to analysis models of shaping kids' health through judo practice, which determines the novelty of our scientific research. Withal, this scientific article is a detailed continuation of those points of view, which were disclosed by us earlier [46-52].

\section{Research methodology}

Organization of the research. The organizational and research's structure of the forming natural closed sequential pedagogical experiment (according to the scheme of a single difference) included twenty groups with a total volume of one hundred and twenty six kids for eleven years of work (we took into account data, concerning kids, which were included in the implementation of at least fifty percent; and we didn't take into account data, concerning kids, which attended lessons selectively, were included in the implementation less than fifty percent of the total number of lessons). Taking into account the fact of solving of teaching problems within the framework of the proposed programs of educational and training lessons (seven methods have been tested) and according to the main provisions of the theory and methodology of physical culture in terms of teaching of motor actions, it is necessary, that the group does not exceed eight kids for one and a half of the hour's lessons (kids mainly of the first year of study - "not immersed" earlier in the culture of judo / large homogeneous groups) or fourteen-sixteen kids for two-hour's lessons [for complex groups of kids of different years of study, where at least a third of them are trainer's assistants (a subgroup of assistants), and, moreover, there are those, who have been practicing in judo for at least several years - the number of sufficient years to be assigned to this subgroup is determined by the kid's giftedness and his preparedness], from our point of view, the volume of the revealed information is sufficient for defining of the effectiveness of these seven methods proposed for implementation.

Research methods (according to the classification of B. G. Ananyev in the modification of E. R. Yakhontov [53] for sports and pedagogical researches and with the author's supplement): comparative method, longitudinal method, a method of included pedagogical observation, a method of recording, a method of photographing, a method of video-filming, a method of control tests, a forming natural closed sequential pedagogical experiment (according to the scheme of a single difference), a method of case studies, correlation's analysis, genetic method, theoretical modeling.

\section{Research results}

\subsection{The author's conception of the health's formation of Russian judokas, including judokas of preschool age}

It is substantiated, that the author's model of four-dimensional judo includes the following levels, their functional and structural components.

Thus, the social (socio-psychological) level of judo interpretation (Table 1) concerns the formation of social qualities and communicative abilities of the adept. In this case, the 
object of influence is "overconsciousness", the pedagogical results at this level are socialization and good breeding. At this, the first and the highest, level of interpretation judo is considered as a technology of the human social health's formation.

Table 1. The range of scientific analysis of the social (socio-psychological) dimension of judo in the context of the formation of the health of its adept.

\begin{tabular}{|c|c|c|c|c|}
\hline Giftedness & Impact object & Abilities & Qualities (achievements) & Human's health \\
\hline social & $\begin{array}{c}\text { Overconsciousness } \\
\text { (socialization and } \\
\text { good breeding) }\end{array}$ & $\begin{array}{c}\text { communic } \\
\text { ative }\end{array}$ & social & social \\
\hline
\end{tabular}

The spiritual (cultural-gnoseological) level of judo interpretation (Table 2) is related to the formation of spiritual qualities, intellectual and cultural-translational abilities of the adept. At this, the second, level of judo interpretation the object of influence is the spirit (consciousness), and judo is viewed as a technology of the human spiritual health's formation (as media technology).

The soulful (intuitive / properly creative) level of judo interpretation (Table 3) is comparable to the formation of mental qualities, creative and volitional abilities of the adept. At this, the third, level of judo interpretation the object of influence is the soul (subconsciousness and unconsciousness), and judo is considered as a technology of the human soulful health's formation.

Table 2. The range of scientific analysis of the spiritual (cultural-gnoseological) dimension of judo in the context of the formation of the health of its adept.

\begin{tabular}{|c|c|c|c|c|}
\hline Giftedness & Impact object & Abilities & $\begin{array}{c}\text { Qualities } \\
\text { (achievements) }\end{array}$ & Human's health \\
\hline $\begin{array}{c}\text { Spiritual } \\
\text { (leadership) }\end{array}$ & $\begin{array}{c}\text { Spirit } \\
\text { (consciousness) }\end{array}$ & $\begin{array}{c}\text { intellectual, } \\
\text { cultural-translational }\end{array}$ & spiritual & spiritual \\
\hline
\end{tabular}

Table 3. The range of scientific analysis of the soulful (intuitive / properly creative) dimension of judo in the context of the formation of the health of its adept.

\begin{tabular}{|c|c|c|c|c|}
\hline Giftedness & Impact object & Abilities & $\begin{array}{c}\text { Qualities } \\
\text { (achievements) }\end{array}$ & Human's health \\
\hline soulful & $\begin{array}{c}\text { soul (subconsciousness } \\
\text { and unconsciousness) }\end{array}$ & $\begin{array}{c}\text { creative, } \\
\text { volitional }\end{array}$ & soulful & soulful \\
\hline
\end{tabular}

The physical (bodily) level of judo interpretation (Table 4) corresponds to the formation of physical qualities, physical abilities and motor skills. At this, the fourth and the lowest, level of judo interpretation the object of influence is the body, and judo is considered as a technology of the human physical health's formation (a system of personality's physical culture's forming in the narrow sense of the word).

The psycho-corporal level of judo interpretation correlates with the formation of psycho-corporal abilities and motor skills (Table 5). At the complex level of judo interpretation, which includes the synthesis of its spiritual, soulful and physical dimensions, the object of influence is, therefore, the synthesis of spirit, soul and body, and judo is considered as a technology of the human psycho-corporal health's formation (a system of personality's physical culture's forming in the broad sense of the word). 
Table 4. The range of scientific analysis of the physical (bodily) dimension of judo in the context of the formation of the health of its adept.

\begin{tabular}{|c|c|c|c|c|}
\hline Giftedness & Impact object & Abilities & $\begin{array}{c}\text { Qualities } \\
\text { (achievements) }\end{array}$ & $\begin{array}{c}\text { Human's } \\
\text { health }\end{array}$ \\
\hline $\begin{array}{c}\text { Physical } \\
\text { (bodily) }\end{array}$ & body & physical & $\begin{array}{c}\text { physical qualities and } \\
\text { motor skills }\end{array}$ & physical \\
\hline
\end{tabular}

Table 5. The range of scientific analysis of the psycho-corporal dimension of judo in the context of the formation of the health of its adept.

\begin{tabular}{|c|c|c|c|c|}
\hline Giftedness & Impact object & Abilities & $\begin{array}{c}\text { Qualities } \\
\text { (achievements) }\end{array}$ & Human's health \\
\hline psychomotor & spirit + soul + body & psycho-corporal & motor skills & psycho-corporal \\
\hline
\end{tabular}

\subsection{The analyze of the components of the author's pedagogical model of health's formation among Russian judokas of preschool age}

As shown in Figure 1, the system of interaction "human - human" allows us to assess the social (social-psychological) judo's dimension, which correlates with the level of judo's understanding in the communication's format.

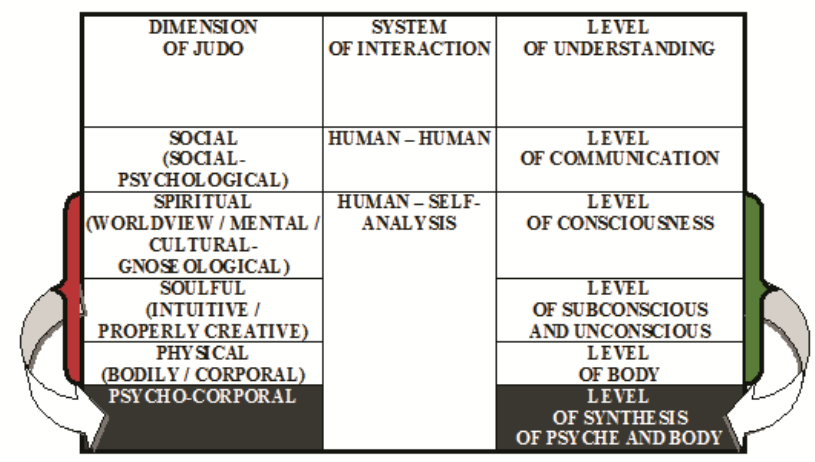

Fig. 1. The relationships between judo's dimensions and judo's levels of understanding.

Also, the analysis of Figure 1 allows us to conclude, that the system of interaction "human - self-analysis" allows us to assess the psycho-corporal judo's dimension, which correlates with the level of judo's understanding in the format of synthesis of the psyche and of the body. In particular, due to the fact, that the psycho-corporal judo's dimension, as mentioned earlier, includes its spiritual, soulful and physical dimensions, then, accordingly, the spiritual (worldview / mental / cultural-gnoseological) judo's dimension correlates with the level of judo's understanding in the consciousness's format, while the soulful (intuitive / properly creative) judo's dimension is compared with the level of judo's understanding in the format of subconscious and unconscious, and, finally, the physical (bodily / corporal) judo's dimension concerns the judo's understanding in the body's format.

It has been revealed (see Figure 2), that the formation of the health of preschool judokas is based on their inclinations, so, that is based on the natural health of the preschooler, and heredity is the sphere of its manifestation and formation.

So, one of the most significant inclinations in the context under consideration is giftedness, which includes the following components: in the mirror of the system of 
interaction "human - human" at the communication's level - the social giftedness of the preschooler, in the mirror of the system of interaction "human - self-analysis" at the level of consciousness - the spiritual (leading) giftedness of the preschooler, at the level of the subconscious and the unconscious - the soulful giftedness of the preschooler, at the level of body - the physical (bodily) giftedness of the preschooler, and, as a result, at the level of synthesis of psyche and body - the psycho-motor giftedness of the preschooler.

\begin{tabular}{|c|c|}
\hline \multirow{8}{*}{$\begin{array}{l}\text { DIMENSION } \\
\text { OF JUDO }\end{array}$} & MEANSOF IMPLEMENTATION \\
\hline & $\begin{array}{l}\text { INCLINATIONS OF THE } \\
\text { PRESCHOOLER }\end{array}$ \\
\hline & TYPES AND COMPONENTS \\
\hline & OF HEALTH IN THE MIRROR \\
\hline & $\begin{array}{c}\text { OF JUDO'S COMPONENTS } \\
\text { NATURAL HEALTH }\end{array}$ \\
\hline & OF THE PRESCHOOLER \\
\hline & HEREDITY AS A SPHERE \\
\hline & $\begin{array}{l}\text { OF MANIFESTATION } \\
\text { AND FORMATION }\end{array}$ \\
\hline $\begin{array}{c}\text { SOCIAL } \\
\text { (SOCIAL- } \\
\text { PSYCHOLOGICAL) }\end{array}$ & $\begin{array}{l}\text { SOCIAL GIFTEDNESS } \\
\text { OF THE PRE SCHOOLER }\end{array}$ \\
\hline \multirow{3}{*}{$\begin{array}{c}\text { SPIRITUAL } \\
\text { (WORLDVIE W / MENT AL / } \\
\text { CULTURAL- } \\
\text { GNOSE OLOGICAL) }\end{array}$} & SPIRITUAL (LE ADING) \\
\hline & GIFTEDNESS \\
\hline & OF THE PRESCHOOLER \\
\hline \multirow{2}{*}{$\begin{array}{c}\text { SOULFUL } \\
\text { (INTUITIVE / } \\
\text { PROPERLY CREATIVE) }\end{array}$} & SOULFUL GIFTEDNESS \\
\hline & OF THE PRESCHOOLER \\
\hline \multirow{2}{*}{$\begin{array}{c}\text { PHYSICAL } \\
\text { (BODILY / CORPORAL) }\end{array}$} & PHYSICAL (BODILY) GIFTEDNESS \\
\hline & OF THE PRE SCHOOLER \\
\hline \multirow[t]{5}{*}{ PSYCHO-CORPORAL } & PSYCHO-MOTOR GIFTEDNESS \\
\hline & OF THE PRESCHOOLER \\
\hline & BASIS \\
\hline & GIFTEDNESS \\
\hline & OF THE PRESCHOOLER \\
\hline
\end{tabular}

Fig. 2. The relationships between judo's dimensions and the means of implementation of the judo's content in the context of the formation of the natural health of the preschooler.

It has been revealed, that the judo's practice as a life principle and the judo's practice as the eastern system of personal physical culture's formation are among the ways of health's formation for preschool judokas.

As shown in Figure 3, the judo's practice as a life principle is considered by us as the judo's practice number one. The judo's practice number one includes: the praxeologically oriented communication (social dimension), the orientalization (spiritual dimension), the practice of Zen's cognition (soulful dimension) and the practice of stimulating endurance's formation (physical dimension), and, in general, on the psycho-corporal dimension - the practice of psychic stability's forming (psychosustainability). It has been reasoned, that the judo's practice number one is based on the intellectual / academic giftedness of the preschooler (general abilities of the preschooler, G-factor according to Charles Spirman) and concerns the formation of preschooler's abilities to optimally adaption to changing nonextreme environmental conditions. In addition, the judo's practice number one, as a whole, determines the adaptive health of the preschooler, and vital activity is the sphere of its manifestation and formation. In particular, in the mirror of the system of interaction "human - human" at the communication's level the social health of the preschooler is formed, in the mirror of the system of interaction "human - self-analysis" at the level of consciousness the spiritual health of the preschooler is formed, at the level of the subconscious and the unconscious the soulful health of the preschooler is formed, at the level of body - the physical health of the preschooler is formed, and, as a result, at the level of synthesis of psyche and body the psycho-corporal health of the preschooler is formed. 


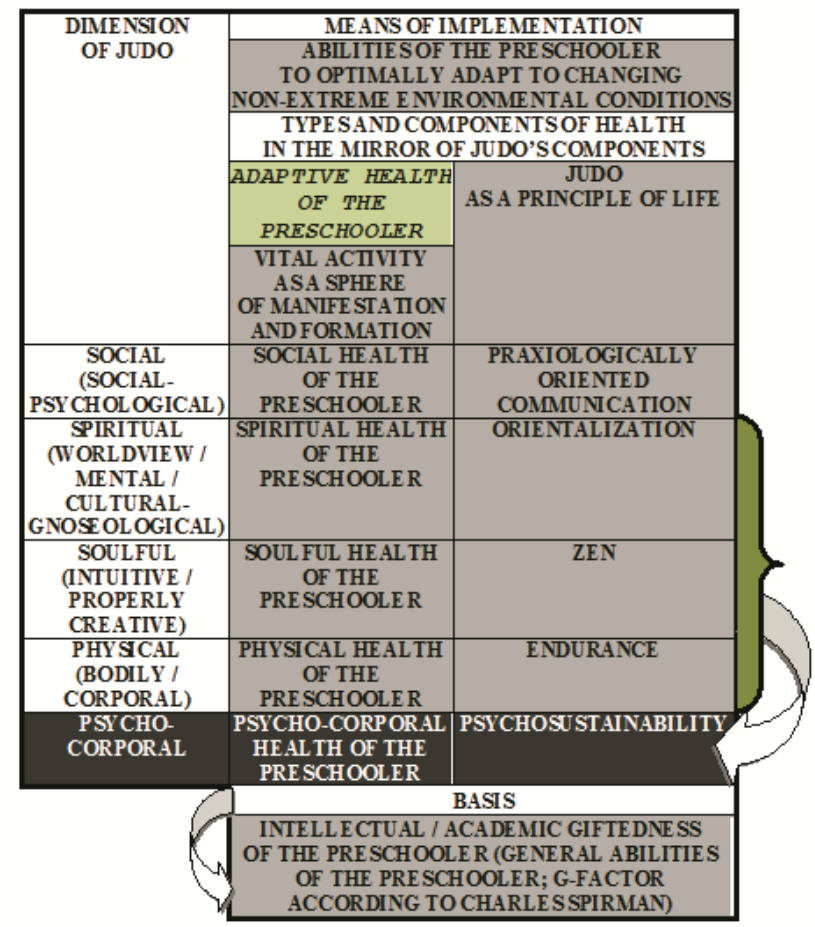

Fig. 3. The relationships between judo's dimensions and the means of implementation of the judo's content in the context of the formation of the adaptive health of the preschooler.

In turn, the judo's practice as the eastern system of personal physical culture's formation is considered by us as the judo's practice number two. As shown in Figure 4, the judo's practice number two includes: ikoe, tsukuri, kake, kuzushi and kimi (social dimension), bushido and etiquette (spiritual dimension), the practice of forming extrasensory abilities (soulful dimension), a-un, teisho, ukemi and shintai-tai-sabaki (physical dimension), and, in general, on the psycho-corporal dimension - psycho-corporal practice.

It has been concluded, that the judo's practice number two is based on the sports' giftedness of the preschooler and concerns the formation of preschooler's abilities to optimally using of the reserved capacities of the organism in changing extreme environmental conditions. In addition, the judo's practice number two, as a whole, determines the buffer health of the preschooler, and training process is the sphere of its manifestation and formation. In particular, in the mirror of the system of interaction "human - human" at the communication's level the social development of the preschooler is occured, in the mirror of the system of interaction "human - self-analysis" at the level of consciousness the spiritual development of the preschooler is occured, at the level of the subconscious and the unconscious the soulful development of the preschooler is occured, at the level of body - the physical development of the preschooler is occured, and, as a result, at the level of synthesis of psyche and body the psycho-corporal development of the preschooler is occured. 


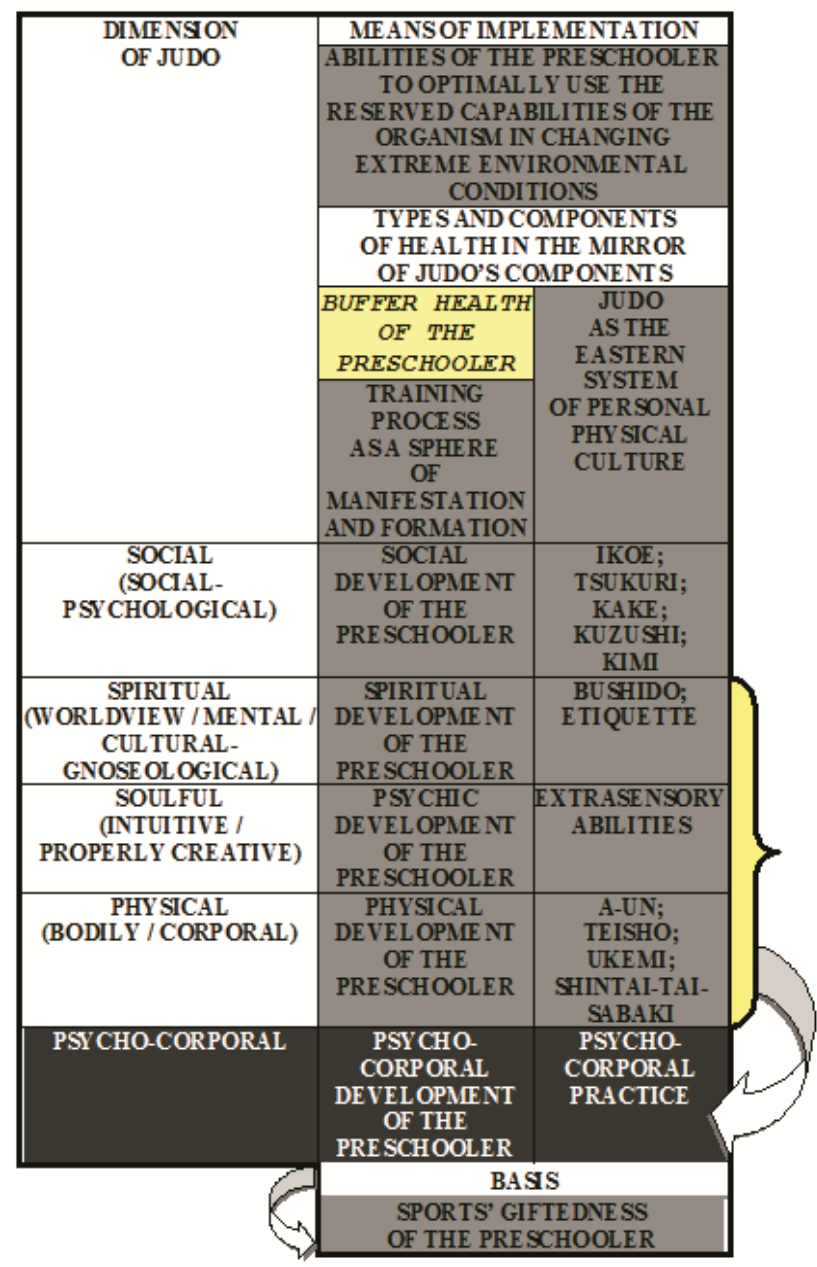

Fig. 4. The relationships between judo's dimensions and the means of implementation of the judo's content in the context of the formation of the buffer health of the preschooler.

\subsection{Evaluation's criteria of health's indicators' formation of preschool kids under the influence of their immersion in judo}

In accordance with the above-considered structure of four-dimensional judo and formed types of health, within the framework of the practice of each dimension of four-dimensional judo, indicators of their formation and their grading criteria were identified, which are given below in Tables 6-10. 
Table 6. The Health Formation's Criteria of Preschool Judokas in the Framework of the Social (Socio-psychological) Dimension of Judo.

\begin{tabular}{|c|c|c|c|}
\hline \multirow{2}{*}{ Index } & \multicolumn{3}{|c|}{ Grading criteria } \\
\hline & low level & medium level & high level \\
\hline $\begin{array}{c}\text { friendli } \\
\text { ness }\end{array}$ & $\begin{array}{l}\text { the index is systematically absent } \\
\text { in relation to anyone (coach / } \\
\text { some judokas / parents) or to all }\end{array}$ & $\begin{array}{l}\text { the index is sporadically absent } \\
\text { in relation to anyone (coach / } \\
\text { some judokas / parents) }\end{array}$ & $\begin{array}{l}\text { the index is } \\
\text { present in } \\
\text { relation to all }\end{array}$ \\
\hline
\end{tabular}

Table 7. The Health Formation's Criteria of Preschool Judokas in the Framework of the Spiritual

(Cultural-gnoseological) Dimension of Judo.

\begin{tabular}{|c|c|c|c|}
\hline \multirow{2}{*}{ Index } & \multicolumn{3}{|c|}{ Grading criteria } \\
\cline { 2 - 4 } & low level & medium level & high level \\
\hline \multirow{3}{*}{$\begin{array}{c}\text { conscious } \\
\text { ness }\end{array}$} & $\begin{array}{c}\text { there are } \\
\text { violations of the } \\
\text { behavior's rules in } \\
\text { the dojo }\end{array}$ & $\begin{array}{c}\text { the index is } \\
\text { present in } \\
\text { behavior in the } \\
\text { dojo }\end{array}$ & $\begin{array}{c}\text { the index is present in behavior in the dojo } \\
\text { and outside the dojo within the organization } \\
\text { (in communication with parents, } \\
\text { employees, other kids) }\end{array}$ \\
\hline
\end{tabular}

Table 8. The Health Formation's Criteria of Preschool Judokas in the Framework of the Soulful (Intuitive / Properly Creative) Dimension of Judo.

\begin{tabular}{|c|c|c|c|}
\hline \multirow{2}{*}{ Index } & \multicolumn{3}{|c|}{ Grading criteria } \\
\hline & low level & medium level & high level \\
\hline intuitiveness & $\begin{array}{c}\text { there are problems } \\
\text { in learning judo } \\
\text { techniques }\end{array}$ & $\begin{array}{l}\text { the kid is easily and } \\
\text { quickly taught judo } \\
\text { techniques }\end{array}$ & $\begin{array}{l}\text { the kid applies the skills to } \\
\text { perform judo techniques in } \\
\text { conditions of resistance / } \\
\text { competition with the "plus" } \\
\text { effect (in new situations) }\end{array}$ \\
\hline $\begin{array}{c}\text { calm self- } \\
\text { confidence } \\
\text { (mental stability) }\end{array}$ & $\begin{array}{l}\text { the kid is restless } \\
\text { in training } \\
\text { conditions }\end{array}$ & $\begin{array}{l}\text { the kid is calm in } \\
\text { training conditions }\end{array}$ & $\begin{array}{l}\text { the kid is calm in training and } \\
\text { competition }\end{array}$ \\
\hline the joy of doing & the index is absent & $\begin{array}{c}\text { the index is } \\
\text { sporadically present }\end{array}$ & the index is always present \\
\hline
\end{tabular}


Table 9. The Health Formation's Criteria of Preschool Judokas in the Framework of the Physical (Bodily) Dimension of Judo.

\begin{tabular}{|c|c|c|c|}
\hline \multirow{2}{*}{ Index } & \multicolumn{3}{|c|}{ Grading criteria } \\
\hline & low level & medium level & high level \\
\hline $\begin{array}{l}\text { functional } \\
\text { preparedness }\end{array}$ & $\begin{array}{l}\text { an increase is in heart rate } \\
\text { by the end of the training } \\
\text { session in the range of } 41 \% \\
\text { or more compared to the } \\
\text { baseline; inadequate } \\
\text { responses to physical } \\
\text { activity (decreased heart } \\
\text { rate by the end of the } \\
\text { training session, } \\
\text { arrhythmias) }\end{array}$ & $\begin{array}{l}\text { an increase is in heart } \\
\text { rate by the end of the } \\
\text { training session in the } \\
\text { range from } 16 \% \text { to } 40 \% \\
\text { compared to the } \\
\text { baseline }\end{array}$ & $\begin{array}{l}\text { an increase is in heart } \\
\text { rate by the end of the } \\
\text { training session in the } \\
\text { range from } 10 \% \text { to } 15 \% \\
\text { compared to the } \\
\text { baseline }\end{array}$ \\
\hline $\begin{array}{c}\text { physical } \\
\text { preparedness }\end{array}$ & $\begin{array}{l}\text { low indicators of the level } \\
\text { of physical abilities' } \\
\text { formation (flexibility, } \\
\text { speed-strength abilities, } \\
\text { complex forms of speed } \\
\text { abilities, strength } \\
\text { endurance, coordination } \\
\text { ability for balance, } \\
\text { accuracy) are in accordance } \\
\text { with general age standards }\end{array}$ & $\begin{array}{l}\text { medium indicators of } \\
\text { the level of physical } \\
\text { abilities' formation } \\
\text { (flexibility, speed- } \\
\text { strength abilities, } \\
\text { complex forms of speed } \\
\text { abilities, strength } \\
\text { endurance, coordination } \\
\text { ability for balance, } \\
\text { accuracy) are in } \\
\text { accordance with general } \\
\text { age standards }\end{array}$ & $\begin{array}{l}\text { high indicators of the } \\
\text { level of physical } \\
\text { abilities' formation } \\
\text { (flexibility, speed- } \\
\text { strength abilities, } \\
\text { complex forms of speed } \\
\text { abilities, strength } \\
\text { endurance, coordination } \\
\text { ability for balance, } \\
\text { accuracy) are in } \\
\text { accordance with general } \\
\text { age standards }\end{array}$ \\
\hline $\begin{array}{l}\text { technical } \\
\text { preparedness }\end{array}$ & $\begin{array}{l}\text { the kid demonstrates the } \\
\text { ability to perform } \\
\text { programmed judo } \\
\text { techniques with serious } \\
\text { errors and inaccuracies in } \\
\text { the absence of resistance }\end{array}$ & $\begin{array}{l}\text { the kid demonstrates the } \\
\text { ability to perform } \\
\text { programmed judo } \\
\text { techniques in the } \\
\text { absence of resistance }\end{array}$ & $\begin{array}{l}\text { the kid demonstrates the } \\
\text { ability to perform } \\
\text { programmed judo } \\
\text { techniques in conditions } \\
\text { of resistance }\end{array}$ \\
\hline
\end{tabular}

Table 10. The Health Formation's Criteria of Preschool Judokas in the Framework of the Psychocorporal Dimension of Judo.

\begin{tabular}{|c|c|c|c|}
\hline \multirow{2}{*}{ Index } & \multicolumn{3}{|c|}{ Grading criteria } \\
\hline & low level & medium level & high level \\
\hline $\begin{array}{l}\text { psycho-corporal } \\
\text { preparedness (the } \\
\text { lack of mental } \\
\text { complexes and } \\
\text { muscle clamps) }\end{array}$ & $\begin{array}{l}\text { the kid holds the pose } \\
\text { for a minute or less in } \\
\text { the Standing Lowen } \\
\text { Arch's test, the kid } \\
\text { holds the pose for a } \\
\text { minute or less in the } \\
\text { Lie Lowen Arch's test }\end{array}$ & $\begin{array}{l}\text { the kid holds the pose for } \\
\text { more than a minute, but } \\
\text { less than three minutes in } \\
\text { the Standing Lowen } \\
\text { Arch's test, the kid holds } \\
\text { the pose for more than a } \\
\text { minute, but less than three } \\
\text { minutes in the Lie Lowen } \\
\text { Arch's test }\end{array}$ & $\begin{array}{l}\text { the kid holds the pose } \\
\text { for more than three } \\
\text { minutes in the } \\
\text { Standing Lowen } \\
\text { Arch's test, the kid } \\
\text { holds the pose for } \\
\text { more than three } \\
\text { minutes in the Lie } \\
\text { Lowen Arch's test }\end{array}$ \\
\hline
\end{tabular}

It has been revealed, that judo is an effective system for the health's formation of preschool kids, allowing to form its social (emphasis on friendliness), spiritual (emphasis on consciousness), soulful (emphasis on intuition, mental stability and joy), physical (emphasis on functional, physical and technical preparedness) and psycho-corporal [emphasis on psycho-corporal preparedness (absence of mental complexes and muscle clamps)] components. 


\subsection{Generalized results of the forming natural closed sequential pedagogical experiment}

It has been disclosed (Figure 5; significant correlation coefficients are indicated by asterisks; considering the small sample size $\mathrm{p} \leq 0.05$; by Spearman's rank correlation coefficient), that a year of study has:

- high positive correlation dependences with the preschool kids' age $(r=0.857)$ and preschool kids' psycho-corporal preparedness $(r=0.793)$;

- very high positive correlation dependences with physical preparedness $(r=0.959)$ and technical preparedness $(\mathrm{r}=0.918)$.

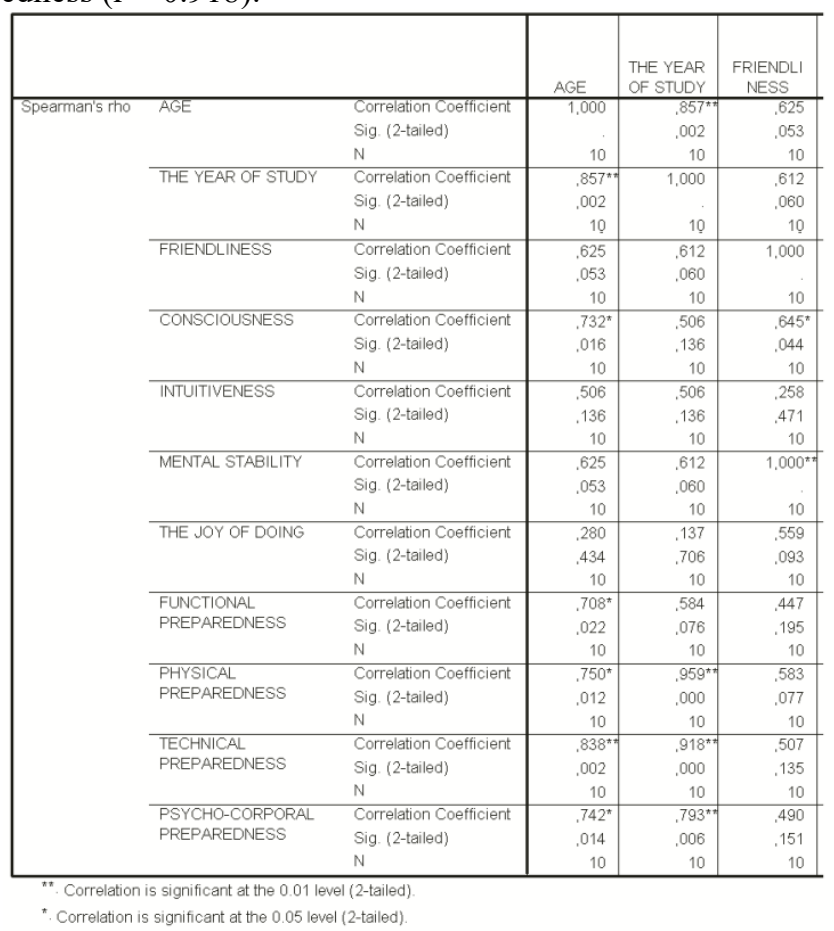

Fig. 5. The correlation analysis matrix of preschool kids' health indexes. Part $1(n=10$; points; significant correlation coefficients are indicated by asterisks; considering the small sample size $\mathrm{p} \leq 0.05$; by Spearman's rank correlation coefficient).

The following facts on the formation of other types of health were also established (Figures 5, 6 and 7; significant correlation coefficients are indicated by asterisks; considering the small sample size $\mathrm{p} \leq 0.05$; by Spearman's rank correlation coefficient):

- the social health of preschoolers has an average positive correlation with their spiritual health $(\mathrm{r}=0.645)$;

- the spiritual health of preschoolers has an average positive correlation with their mental stability $(\mathrm{r}=0.645)$, as well as high positive correlation with the age of preschoolers $(\mathrm{r}=0.732)$, their intuition $(\mathrm{r}=0.700)$ and functional preparedness $(\mathrm{r}=0.808)$;

- the intuition as a parameter of mental health has a high positive correlation with functional preparedness $(\mathrm{r}=0.808)$;

- functional preparedness has an average positive correlation with preschool kids' technical preparedness $(\mathrm{r}=0.680)$ and a high positive correlation with the preschool kids' age $(\mathrm{r}=0.708)$; 
- the physical health of preschoolers has an average positive correlation with their psycho-corporal preparedness $(\mathrm{r}=0.698)$, as well as, the high positive correlation with the preschool kids' age $(\mathrm{r}=0.750)$ and their technical preparedness $(\mathrm{r}=0.859)$;

- technical preparedness has a high positive correlation with the preschool kids' age $(\mathrm{r}=0.838)$.

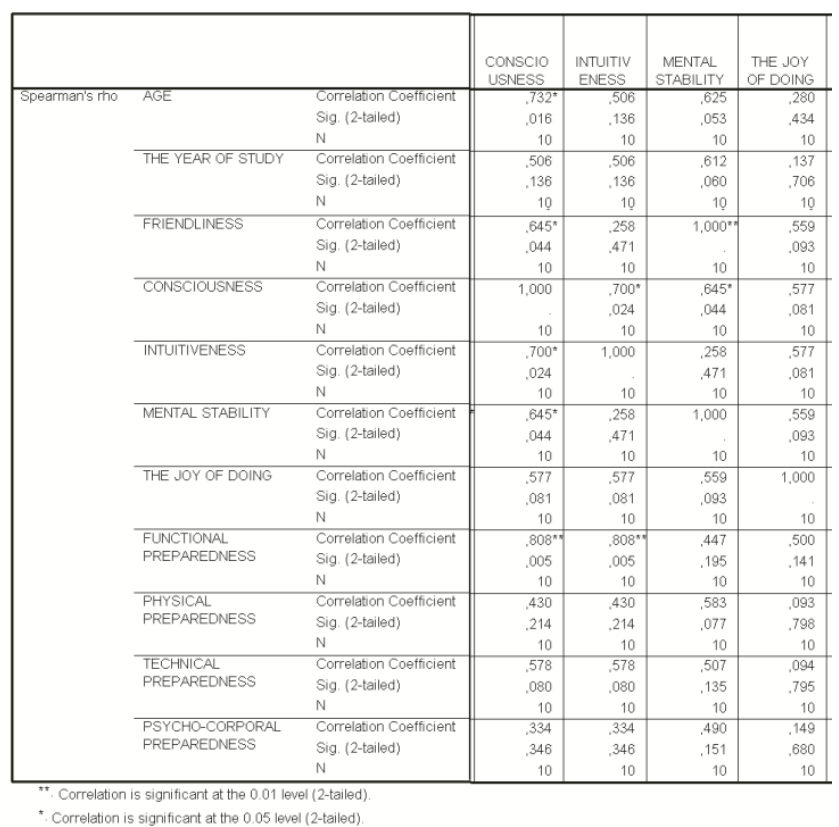

Fig. 6. The correlation analysis matrix of preschool kids' health indexes. Part $2(\mathrm{n}=10$; points; significant correlation coefficients are indicated by asterisks; considering the small sample size $\mathrm{p} \leq 0.05$; by Spearman's rank correlation coefficient).

These results prove that the author's methodology allows preschool kids to fully master the basic parameters of the physical judo's dimension, forming preschool kids' physical health, as well as the psycho-corporal judo' dimension, respectively, forming preschool kids' psycho-corporal health.

It has been proved, that all levels of preschool kids' health at the beginning of the pedagogical experiment have a low level of formation; preschool kids, who have been practicing judo for several years, are characterized by middle and high indicators of social, spiritual, soulful, physical, psycho-corporal health. 


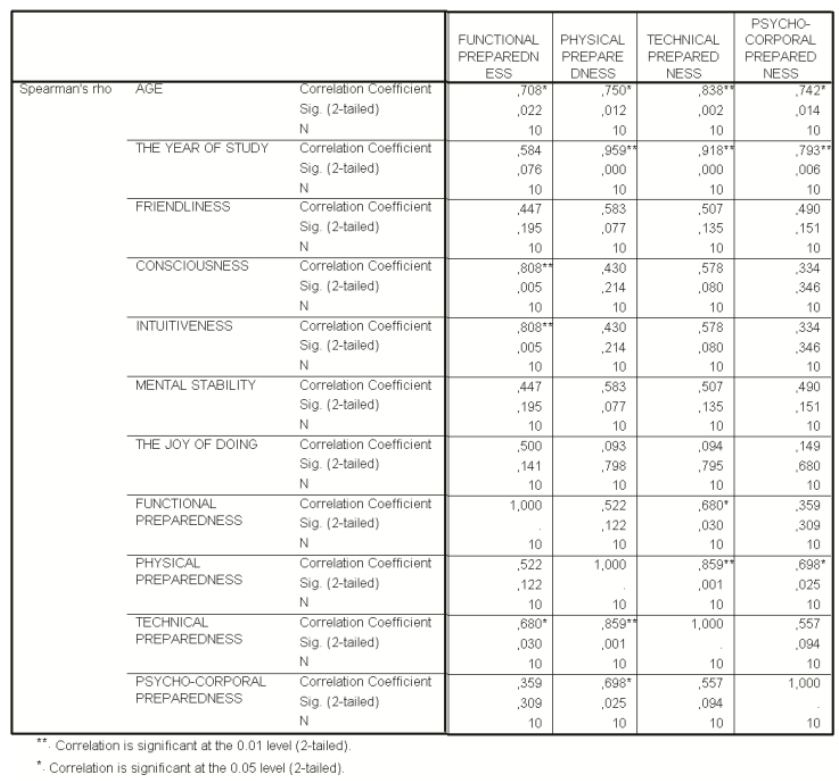

Fig. 7. The correlation analysis matrix of preschool kids' health indexes. Part $3(n=10$; points; ; significant correlation coefficients are indicated by asterisks; considering the small sample size $\mathrm{p} \leq 0.05$; by Spearman's rank correlation coefficient).

\section{Conclusion}

The formation of health among all judokas of the preschool age is necessary and possible through the implementation of the judo's practice number two, that is the judo's practice as the eastern system of personal physical culture's formation, while the judo's practice number one, that is the judo's practice as a life principle, can mainly be available to form the health of only those preschool judokas, who have been already mastering the judo's practice number two, that is, mastering judo involves moving from the physical dimension to the soulful and spiritual dimensions, and, in general, from the psycho-corporal dimension to the social dimension, and not vice versa.

\section{The discussion of the results}

It has been established, that Russian kids' judo coaches practice an educational and training process, which provides for the development of "adapted judo" using either an "adult methods of accentuated natural selection", or methods based on mastering the initial forms of judo exercises, implemented by a game method. The most fundamental and controversial approach is the very fact of mastering "judo for adults" by preschool kids with the using of the adapted methods, which are mastering a number of judo techniques, that are accessible and safe for preschool judokas. The last (our) approach is based on the Japanese approach in terms of expediency, that is, it involves taking into account the methodology of the Japanese - the creators of judo. It is surprising, that the majority of Russian judo specialists reject this approach, preferring to it conducting physical education training sessions in a kimono with some elements of judo (in fact, without mastering a single judo technique at preschool age $[40,41])$, that is, under the slogan "judo" preschool kids are mainly engaged exclusively in physical preparedness. In this regard, it is important to mention, that our 
approach is approved by the European Judo Union [46, 47, 48, 49] and it consists in mastering "judo for adults" using the adapted methods.

The author of this scientific article expresses her sincere gratitude to all involved employees of The Non-state Educational Institution "Private Day-care Center and School 'GROWTH"' (at three objects), of The Development Studio "Peppy Happy", of The Kids' Club "Peppy Happy", of The Physical Culture's and recreation's complex "Ispytateley's Prospekt" and of The Federal State Budget Educational Institution of the Higher Education "National State University of Physical Culture, Sport and Health named after P. F. Lesgaft, Saint-Petersburg".

\section{References}

1. Preamble to the Charter (Constitution) of the World Health Organization, date of treatment: March 24, 2014. URL :

http://apps.who.int/gb/bd/PDF/bd47/RU/constitution-ru.pdf. (In Russian)

2. V. Lobodin, Formula of health, date of treatment: March 24, 2014. URL : http://www.telenir.net/zdorove/formula_zdorovja/index.php. (In Russian)

3. Human spiritual health, date of treatment: March 24, 2014. URL : http://samidoktora.ru/metodiki-ozdorovleniya/duxovnoe-zdorove. (In Russian)

4. World Health Organization, date of treatment: January 11, 2021. URL : https://www.who.int/ru. (In Russian)

5. L. Särkilahti, Teaching judo efficiently. Applied nonlinear pedagogy, Liikuntapedagogiikan pro gradututkielma Liikuntatieteellinen tiedekunta Jyväskylän yliopisto (2020). URL :

https://jyx.jyu.fi/bitstream/handle/123456789/69018/1/URN\%3ANBN\%3Afi\%3Ajyu202005183272.pdf. (Unpublished)

6. M. P. Danilova, V. G. Torgovkin, Modeling of technical-tactical skills of studentsjudokas in university conditions, Theory and Practice of Physical Culture, 2, 78-80 (2013). URL : http://www.teoriya.ru/ru/node/339. (In Russian)

7. R. B. Elipkhanov, Long-term strength training of female judokas, Theory and Practice of Physical Culture, 8, 78-84 (2013). URL : http://www.teoriya.ru/ru/node/728. (In Russian)

8. K. V. Yugay, Strength abilities providing hold efficiency of judokas of different categories, Theory and Practice of Physical Culture, 5, 21 (2014). URL : http://www.teoriya.ru/ru/node/2164

9. A. A. Baryaev, Physical fitness tests in blind sports, Theory and Practice of Physical Culture, 11, 12 (2018). URL : http://www.teoriya.ru/ru/node/9692

10. V. G. Pashintsev, Glycolytic loading in training of judokas, Theory and Practice of Physical Culture, 9, 11 (2013). URL : http://www.teoriya.ru/ru/node/1567

11. A. A. Pseunok, M. A. Mugotlev, M. N. Silantyev, Heart rate and salivary electrolyte concentration in 10-12 year-old judokas, Theory and Practice of Physical Culture, 12, 17 (2018). URL : http://www.teoriya.ru/ru/node/9783

12. S. A. Pelipenko, Development of aerobic-anaerobic working capacity of judokas by means of interval run, Theory and Practice of Physical Culture, 7, 80-84 (2013). URL : http://www.teoriya.ru/ru/node/684. (In Russian)

13. V. G. Pashintsev, A. M. Surkov, Development of speed-strength glycolytic endurance in judo, Theory and Practice of Physical Culture, 3, 6 (2015). URL :

http://www.teoriya.ru/ru/node/3504 
14. V. V. Zebzeev, O. S. Zdanovich, Analysis of special fitness of junior judokas, Theory and Practice of Physical Culture, 2, 68-70 (2013). URL :

http://www.teoriya.ru/ru/node/334. (In Russian)

15. B. Wieslaw, O. Zbigniew, The peculiarities of coaching of young female judokas and their effect on athletic performance, Theory and Practice of Physical Culture, 10, 20 (2014). URL : http://www.teoriya.ru/ru/node/2596.

16. A. V. Volkov, I. A. Panchenko, A. P. Babchenko, Training load volume and goal as key factors of performance control in judo, Theory and Practice of Physical Culture, 7, 24 (2017). URL : http://www.teoriya.ru/ru/node/6666.

17. A. B. Petrov, S. P. Bodko, V. K. Seisebayev, D. A. Pokhachevsky, Training process efficiency criteria in professional sambo and judo sports, Theory and Practice of Physical Culture, 8, 98 (2019). URL : http://www.teoriya.ru/ru/node/10823.

18. S. K. Bagadirova, F. S. Brantova, E. A. Potokova, F. P. Khakunova, Goal-setting in psychological structure of sports activity as a factor of increase of efficiency of judo training process, Theory and Practice of Physical Culture, 8, 17 (2015). URL : $\mathrm{http} / / / \mathrm{www}$. teoriya.ru/ru/node/3965.

19. S. K. Bagadirova, Psychological aspects of design and implementation of training model in judo, Theory and Practice of Physical Culture, 6, 16 (2020). URL : http://www.teoriya.ru/en/node/11894.

20. M. V. Gabov, R. Z. Valeev, Yu. G. Martemyanov, Effectivization of competitive performance of skilled judokas with hearing impairments, Theory and Practice of Physical Culture, 5, 23 (2015). URL : http://www.teoriya.ru/ru/node/3791.

21. I. D. Svishchev, V. A. Chuvilin, Structure of competitive match depending on display of motor activity dominant in judokas, Theory and Practice of Physical Culture, 7, 25 (2015). URL : http://www.teoriya.ru/ru/node/3864.

22. O. Koptev, Competitive competence structure in judo, Human. Sport. Medicine, 18(2), 35-44 (2018). DOI : https://doi.org/10.14529/hsm180204. (In Russian).

23. S. I. Loginov, A. A. Egorov, V. A. Ermakov, Data mining system: "Judo sport school" module, Theory and Practice of Physical Culture, 2, 29 (2015). URL : http://www.teoriya.ru/ru/node/3005.

24. A. F. Zekrin, F. Kh. Zekrin, V. V. Zebzeev, Anthropometric characteristics of junior judokas of different weight groups, Theory and Practice of Physical Culture, 4, 4 (2015). URL : http://www.teoriya.ru/ru/node/3568.

25. T. K. Kim, A. A. Podlesnykh, Rating benefits of musculoskeletal system disorders prevention and correction method based on motor profiles in judo, Theory and Practice of Physical Culture, 1, 32 (2018). URL : http://www.teoriya.ru/ru/node/7937.

26. A. G. Levitsky, D. A. Matveyev, A. A. Potsipun, A. V. Shabaev, Advanced foot sweep (de ashi harai) throw technique in judo: body position analysis, Theory and Practice of Physical Culture, 7, 23 (2016). URL : http://www.teoriya.ru/ru/node/5005.

27. A. G. Levitsky, D. A. Matveyev, A. A. Potsipun, E. Y. Gaponova, Body position control in o-soto-gari throws performed in competitive bouts, Theory and Practice of Physical Culture, 5, 24 (2017). URL : http://www.teoriya.ru/ru/node/6739.

28. A. G. Levitsky, D. A. Matveyev, A. A. Potsipun, O. V. Oshina, O. V. Kholodkova, Biomechanical classification of actions in wrestling, Theory and Practice of Physical Culture, 10, 23 (2017). URL : http://www.teoriya.ru/ru/node/7698. 
29. A. G. Levitsky, D. A. Matveyev, A. A. Potsipun, O. V. Nerobeeva, Hip throw biomechanics analysis for wrestling sports, Theory and Practice of Physical Culture, 8 , 28 (2018). URL : http://www.teoriya.ru/ru/node/9244.

30. D. A. Matveev, A. A. Potsipun, O. V. Oshina, A. G. Levitsky, Throw technique biomechanics in competitive wrestling, Theory and Practice of Physical Culture, 6, 30 (2018). URL : http://www.teoriya.ru/ru/node/8592.

31. A. G. Levitsky, D. A. Matveyev, A. A. Potsipun, O. V. Oshina, Body mass center travel trajectory analysis for ko-uchi-gari in judo bouts, Theory and Practice of Physical Culture, 5, 22 (2019). URL : http://www.teoriya.ru/ru/node/10755.

32. V. A. Adolf, L. K. Sidorov, M. D. Kudryavtsev, A. Y. Osipov, A. Y. Bliznevsky, Precompetitive fitness methods applied by Russian judo teams prior to international events, Theory and Practice of Physical Culture, 9, 22 (2018). URL : http://www.teoriya.ru/ru/node/9431.

33. A. G. Levitsky, V. A. Kuvanov, V. A. Dorofeev, National judo team qualification for 2020 Olympics in Tokyo: strategies, options and prospects, Theory and Practice of Physical Culture, 4, 29 (2019). URL : http://www.teoriya.ru/ru/node/10727.

34. G. A. Kuzmenko, E. A. Kabanova, T. N. Lugovskikh, Psychomotor and speed qualities and mindsets cultivation in junior judokas for competitive progress, Theory and Practice of Physical Culture, 8, 5 (2018). URL : http://www.teoriya.ru/ru/node/8967.

35. E. A. Kabanova, G. A. Kuzmenko, Ch. T. Ivankov, Excelling training of junior heavy weight judokas for high-speed confrontation strategy, Theory and Practice of Physical Culture, 2, 63-65 (2020). URL : http://www.teoriya.ru/ru/node/11309. (In Russian).

36. A. V. Litmanovich, A. A. Martin, V. I. Razumov, Logical scheme based fight control strategies in martial arts: judo case study, Theory and Practice of Physical Culture, 11, 7 (2018). URL : http://www.teoriya.ru/ru/node/9688.

37. A. G. Levitsky, G. V. Rudenko, D. A. Simakov, Tactical problem solving algorithms for judokas of various skill levels, Theory and Practice of Physical Culture, 4, 80-82 (2020). URL : http://www.teoriya.ru/ru/node/11498. (In Russian).

38. Ya. I. Yakovlev, I. I. Druziyanov, N. D. Kronnikov, S. V. Semenov, National sports fundamental for olympic accomplishments of yakut athletes, Theory and Practice of Physical Culture, 7, 35 (2018). URL : http://www.teoriya.ru/ru/node/8871.

39. M. Tkachuk, A. Levitskii, A. Sobolev, Morphogenetic markers of fast trainability in wrestling, Human. Sport. Medicine, 19(1), 130-134 (2019). DOI : https://doi.org/10.14529/hsm190118. (In Russian).

40. S. V. Eregina, K. N. Tarasenko, Judo training of preschoolers aged 3-6 years: structure and content, Physical culture: upbringing, education, training, 3, 56-58 (2020). URL : http://www.teoriya.ru/ru/node/12591. (In Russian).

41. S. V. Eregina, K. N. Tarasenko, Theoretical approaches to sportization of preschool physical education, Physical culture: upbringing, education, training, 4, 60-62 (2020). URL : http://www.teoriya.ru/ru/node/12565. (In Russian).

42. O. V. Borisenko, S. I. Loginov, L. I. Lubysheva, The influence of training experience on morphofunctional indices and physical fitness of male judokas aged $8-10$, Theory and Practice of Physical Culture, 12, 19 (2013). URL : http://www.teoriya.ru/ru/node/1716.

43. O. O. Gagarina, Technology of teaching junior judokas flying rolls based on the use of orientation basis of actions and allocation of main reference points, Physical culture: upbringing, education, training, 6, 39-41 (2014). URL : http://www.teoriya.ru/ru/node/3176. (In Russian). 
44. O. V. Borisenko, S. I. Loginov, L. I. Lubysheva, Development of coordination abilities in primary school age children using judo in context of modular technology, Theory and Practice of Physical Culture, 6, 24 (2015). URL : http://www.teoriya.ru/ru/node/3828.

45. L. V. Pertseva, M. S. Ponomareva, A. V. Belyaeva, Benefits of Sakha ethnic sports for physical progress in beginner judo trainings, Theory and Practice of Physical Culture, 10, 26 (2019). URL : http://www.teoriya.ru/ru/node/11664.

46. D. A. Mikhaylova, A. G. Levitsky, S. E. Tabakov, Actor's training's exercises' using on judo studies with Russian preschool kids, 1st European Science of Judo Symposium, 21 April 2010, Vienna, Austria, 26-27 (2010), date of treatment: August 14, 2020. URL :

https://attachments.eju.net/1st\%20European\%20Science\%20of\%20Judo\%20Symposiu m\%20Booklet.pdf.

47. D. A. Mikhaylova, A. G. Levitsky, From the classification of judo's technique - to its teaching's sequence, 2nd European Science of Judo Poster Exhibition, 21 April 2011, Istanbul, Turkey, 36-37 (2011), date of treatment: August 14, 2020. URL : https://attachments.eju.net/2nd\%20European\%20Science\%20of\%20Judo\%20Symposi um\%20Booklet.pdf.

48. D. A. Mikhaylova, A. G. Levitsky, The variants of a technology of judo's teaching for different groups of the Russian preschool kids, 3rd European Science of Judo Poster Exhibition, 26 April 2012, Chelyabinsk, Russia, 30-31 (2012), date of treatment: August 14, 2020. URL :

https://attachments.eju.net/3rd\%20European\%20Science\%20of\%20Judo\%20Symposiu $\mathrm{m} \% 20$ Booklet.pdf.

49. D. A. Mikhaylova, A. G. Levitsky, The preparation's technique of non-oriental made judo contestants' of preschool age, 4th European Science of Judo Poster Exhibition, 25 April 2013, Budapest, Hungary, 20-21 (2013), date of treatment: August 14, 2020. URL :

https://attachments.eju.net/4th\%20European\%20Science\%20of\%20Judo\%20Symposiu m\%20Booklet.pdf.

50. D. A. Mikhaylova, A. G. Levitsky, G. V. Rudenko, Ways of Acculturation to Physical Culture Depending on Level of Organization of Physical Activity in Free Time, Theory and Practice of Physical Culture, 11, 14 (2014). URL : http://www.teoriya.ru/ru/node/2608.

51. D. A. Mikhaylova, A. G. Levitsky, Innovative technologies in the elect sport of the highest achievements (judo). Safe judo for kids of 2-6 (7) years old, scientific monograph, St. Petersburg, Publishing House "Olymp-SPb”, 128 (2014). (In Russian).

52. D. A. Mikhaylova, A. G. Levitsky, L. S. Uzun, Safe judo. Application of modified exercises of K. S. Stanislavsky's system as an element of the methodology of mastering judo by modern Russian children 2-7 (8) years old, Actual problems of physical and special training of power structures [scientific peer-reviewed journal (part one)], 3 , 106-112 (2016). (In Russian).

53. E. R. Yakhontov, Methodology of sports and pedagogical research, a course of lectures, St. Petersburg State Academy of Physical Culture named after P. F. Lesgaft, St. Petersburg, [without publisher], 42-50 (2002). (In Russian). 